\title{
43. A SEISMIC COMPARISON OF THE EARLY STRATIGRAPHIC EVOLUTION OF CONJUGATE PASSIVE CONTINENTAL MARGINS: THE NEWFOUNDLAND/FLEMISH BASIN AND THE EASTERN IBERIAN ABYSSAL PLAIN SOUTH OF GALICIA BANK ${ }^{1}$
}

\author{
Karen J. Meador and James A. Austin, Jr., Institute for Geophysics, University of Texas, Austin, Texas
}

\begin{abstract}
The Newfoundland/Flemish Basin and its conjugate passive margin, the northwestern Iberian Peninsula, were contiguous in the late Early Cretaceous. Therefore, we infer that these margins were subject to similar tectonic and sedimentary processes during their early evolution. A comparison of these conjugates using multichannel seismic-reflection (MCS) profiles shows similar acoustic basement in the Newfoundland/Flemish Basin underlying the J anomaly (M0M1) and beneath the Iberian Abyssal Plain at a peridotite ridge interpreted as a mantle diapir. ODP Leg 103 sampled the peridotite ridge at Site 637, and although the crust at Site 637 exhibits no anomalous magnetic signature, it is collinear with the $\mathrm{J}$ anomaly trend southeast of the Grand Banks of Canada in a previous pre-drift reconstruction.

Both margins exhibit a high-amplitude, rhythmically layered "rift" sequence bounded at the top by a prominent, high-amplitude sequence boundary interpreted to be a break-up unconformity of late Early Cretaceous age. The early "drift" sequences on both margins consist of lower amplitude, discontinuous reflections to which we assign an early Albian to Cenomanian age. Results of these comparisons support developing correlations between Grand Banks stratigraphy and the deep Newfoundland/Flemish Basin, and are consistent with our current interpretation of the nature of the Newfoundland/Flemish Basin crust and the position of the ocean/continent boundary off this part of eastern Canada.
\end{abstract}

\section{INTRODUCTION}

\section{Purpose of this Study}

The early evolution of passive continental margins, namely the timing of events such as crustal thinning, faulting, subsidence, and early seafloor spreading, can be studied most effectively through the comparison of conjugates. The Newfoundland/Flemish Basin is located in the western North Atlantic off eastern Canada, southeast of the Grand Banks. Its conjugate margin is the northwestern Iberian Peninsula south of Galicia Bank (Fig. 1). Pre-drift plate reconstructions of this part of the North Atlantic (e.g., Le Pichon et al., 1977; Klitgord and Schouten, 1986) suggest that in the late Early Cretaceous, when Flemish Cap and Galicia Bank were juxtaposed, a gap that was only approximately $1100 \mathrm{~km}$ wide separated the southeastern Grand Banks and the northwestern Iberian Peninsula (Fig. 2). As a result, we infer that the rift/early drift stratigraphic frameworks of the Newfoundland/Flemish Basin and the Iberian margin south of Galicia Bank should be similar. Furthermore, the ages established for rift/early drift sequences at Deep Sea Drilling Project (DSDP) Site 398 on the eastern part of the Iberian Abyssal Plain (Groupe Galice, 1979) and further documented by Ocean Drilling Program (ODP) Leg 103 results (Boillot, Winterer, et al., 1987) are comparable to ages recently correlated from well control on the southeastern Grand Banks to the deep northern Newfoundland/Flemish Basin (Meador et al., 1985, in press; Austin et al., 1987; Meador, 1988).

In this report, we compare interpreted rift/early drift seismic sequences of the northern Newfoundland/Flemish Basin to the coeval seismic stratigraphy of the Galicia passive margin. We also compare the structural characteristics of acoustic basement near ODP Site 637, which sampled a peridotite ridge near an inferred ocean/continent crustal boundary south of Galicia Bank, to the acoustic basement of the Newfoundland/Flemish Basin near the $\mathbf{J}$ magnetic anomaly, which has been interpreted as

\footnotetext{
${ }^{1}$ Boillot, G., Winterer, E. L., et al., 1988. Proc. ODP, Sci. Results, 103: College Station, TX (Ocean Drilling Program).
}

marking the onset of seafloor spreading off eastern Canada (Sullivan, 1983; Klitgord and Schouten, 1986; Austin et al., in press).

We conclude that the ocean/continent boundaries and rift/ early drift sequences of the two conjugate margins have similar seismic character and are approximately the same age. We also suggest that on passive margins where no well control exists, comparative seismic studies can be used to constrain early geologic history, including the relative timing of initial continental breakup and the onset of seafloor spreading.

\section{Data Base}

This study is based on integration of the following data sets:

1. The northern portion of a regional grid of MCS lines (Fig. 3) and magnetics (Fig. 4), gravity, and sonobuoy data, collected in the Newfoundland/Flemish Basin (labeled "NB") in August 1984 by the University of Texas Institute for Geophysics (UTIG) and Woods Hole Oceanographic Institution (WHOI) aboard the Lamont-Doherty Geological Observatory (LDGO) research vessel Robert D. Conrad (exact acquisition parameters are shown in Table 1). These seismic data have been processed at UTIG using DISCO processing software on a VAX 11/780 computer. Standard processing includes demultiplexing, merging of Loran C/transit satellite navigation inputs (performed at LDGO), static correction, debubbling, source/receiver/common-depthpoint (CDP) geometry definition, CDP sort (25-m bin spacing), velocity analysis (using constant velocity stacks), normal moveout correction, stacking, predictive deconvolution, trace mix, trace decimation, finite-difference time migration, time varying band-pass filtering, and automatic gain control.

Magnetic anomalies have been calculated from total field measurements in order to identify and examine the coherence and variation of the J anomaly along strike (Fig. 4). The magnetics and gravity data have also aided interpretation of acoustic basement features in the Newfoundland/Flemish Basin (Austin et al., in press; Meador, 1988). This task has also benefited from wide-angle reflection/refraction profiles using expendable sonobuoys; these profiles were collected along with the MCS profiles and processed at WHOI using software available there. 


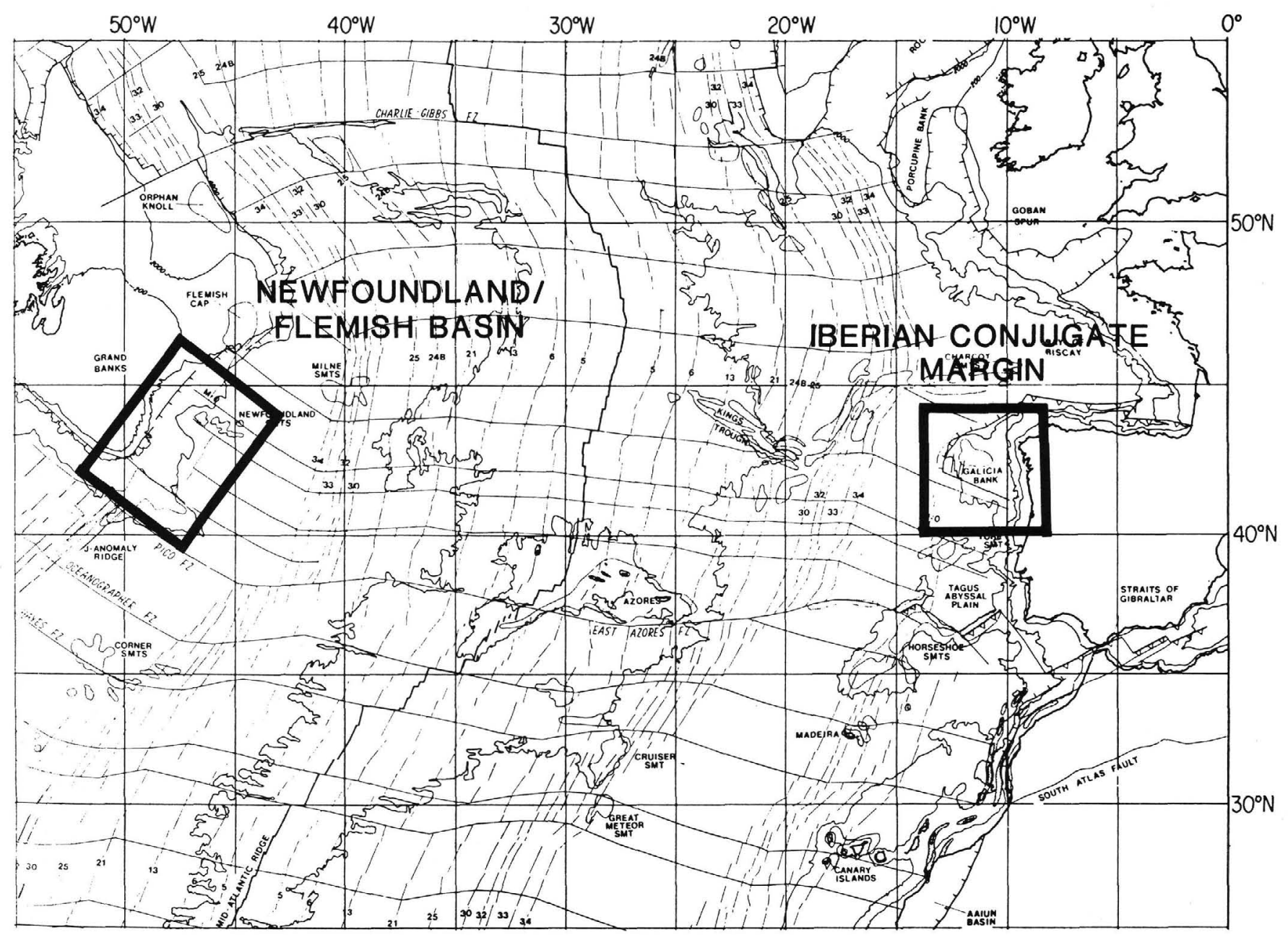

Figure 1. Present plate tectonic configuration of part of the North Atlantic, modified from Klitgord and Schouten (1986). Boxes show locations of the Newfoundland/Flemish Basin and its conjugate passive margin off the northwestern Iberian Peninsula.

2. MCS lines (Fig. 3) collected by industrial sources and purchased from Canada Oil and Gas Lands Administration (COGLA). These include "GAD" lines (24-fold; 1200 -in. ${ }^{3}$ air gun array) from a 1972 survey by Geophysical Services, Inc. (G.S.I.); "GAA" lines (48-fold) from a 1971 survey by G.S.I.; "CG" lines (48-channel, 24-fold; "vaporchoc") from a 1973 survey by Compagnie Générale de Géophysique (CGG) for Texaco Exploration Canada, Ltd.; "XCB" lines (24-channel, 24fold; Vibroseis) from a 1972 survey by Seiscan Delta, Ltd.; and "CAM" lines (24-fold) from a 1973 survey by G.S.I. for Chevron.

3. Single-channel "Farn" profiles, collected in 1981 by the Institute of Oceanographic Sciences (I.O.S.), U.K., aboard the research vessel Farnella (courtesy of L. M. Parson, I.O.S.).

4. Lithology logs from the Amoco-Imperial Oil-Skelly Skua E-41 well (see Fig. 3) (obtained from Riley's Data Service, Calgary, Alberta, Canada) and velocity data from a downhole check shot survey of that well conducted for Amoco Canada Petroleum Company, Ltd. (also made available by COGLA).

5. Previously interpreted rift/early drift stratigraphy of the eastern part of the Iberian Abyssal Plain sampled at DSDP Site 398 and imaged by a nearby seismic line (GP-19; Group Galice, 1979).

6. Drilling results from ODP Leg 103 (Sites 637, 638, 639, and 641; Boillot, Winterer, et al., 1987).

\section{NEWFOUNDLAND/FLEMISH BASIN SEISMIC STRATIGRAPHY}

The late rift/early drift seismic stratigraphy of the Newfoundland/Flemish Basin (Meador et al., 1985, in press; Austin et al., 1987) has been developed by the correlation of dated lithologies in the Skua E-41 well on the Grand Banks with acoustic horizons on MCS line NB-2, which crosses the well bore (Fig. 3). Part of the NB-2 acoustic succession has been successfully correlated eastward into the deep Newfoundland/Flemish Basin using both NB dip lines and nearby industry MCS control (Fig. 3), although these correlations have been hampered by the presence of a basement hinge zone on the shelf margin (Jansa et al., this volume), interpreted salt diapirs (Austin et al., in press), and interpreted continental(?) basement blocks along parts of the shelf/slope break (Meador et al., 1985; Austin et al., 1987). The seismic stratigraphic framework developed for the northern Newfoundland/Flemish Basin is now being compared by Meador (1988) both to that characterizing the basin as a whole (Parson et al., 1985) and to stratigraphic successions developed for other parts of the western North Atlantic basin (e.g., Jansa and Wade, 1975; Tucholke and Mountain, 1979, 1986).

\section{Acoustic Basement}

The J anomaly (Figs. 2 and 4) has been interpreted by Sullivan (1983) and, more recently, by Masson and Miles (1984) and 


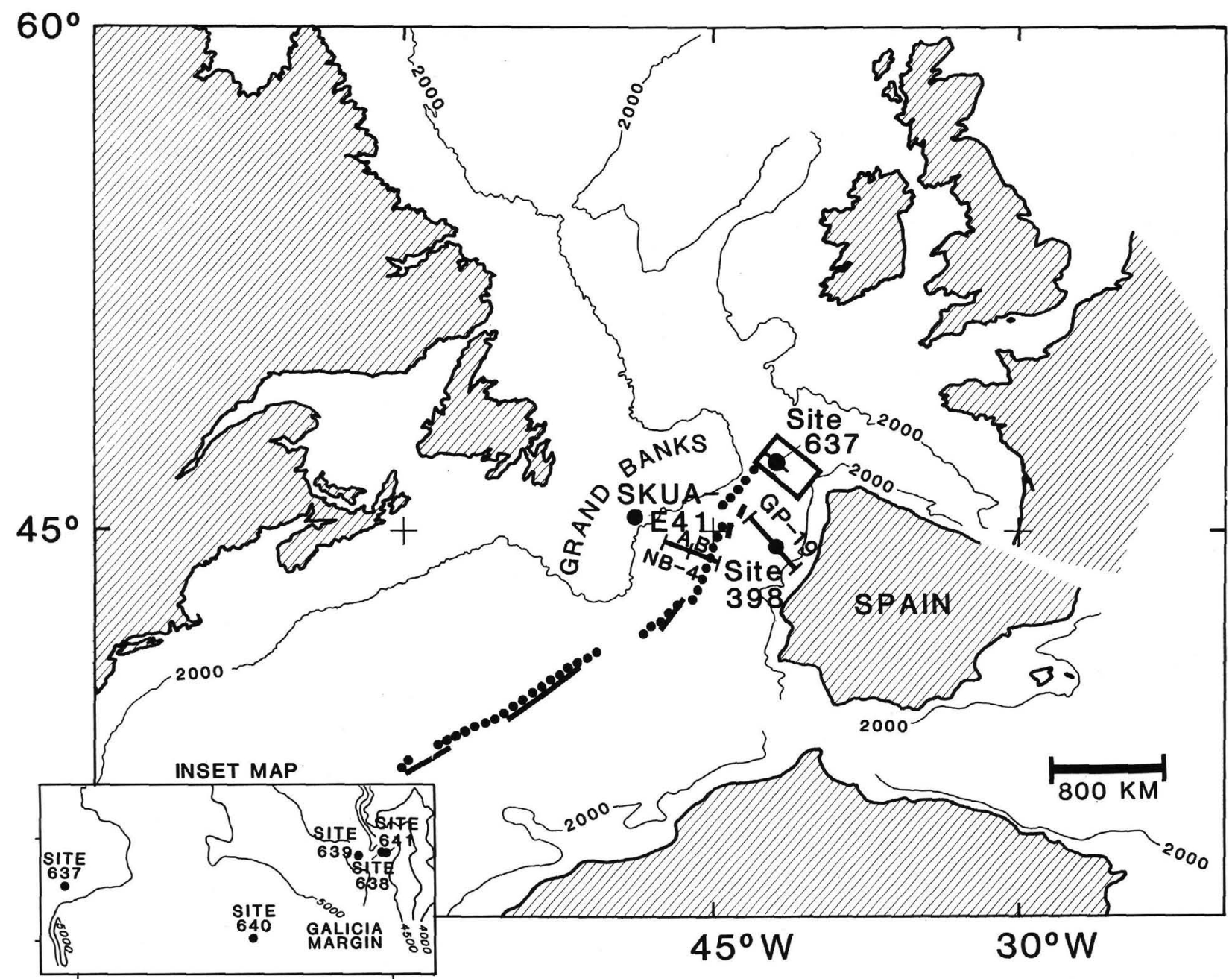

Figure 2. Reconstruction by Le Pichon et al. (1977) of the North American and Iberian plates at J anomaly time (late Early Cretaceous). In this reconstruction, the position of North America is held fixed and the $\mathrm{J}$ anomaly is used as an isochron to close the North Atlantic Basin. Parts of the J anomaly identified on the North American margin are represented by the dashed line, whereas parts of the same anomaly interpreted along the Iberian margin are represented by the dotted line (after Meador et al., in press). Box shows the location of the inset (lower left, modified from Boillot, Winterer, et al., 1987) with locations of the ODP Leg 103 drill sites.

Klitgord and Schouten (1986), to be the oldest seafloor-spreading anomaly in the Newfoundland/Flemish Basin. Keen et al. (1977) and Sullivan (1983) have estimated that the J anomaly in the Newfoundland/Flemish Basin is of late Early Cretaceous (M0-M1) age, as confirmed for this feature's original identification southwest of the Southeast Newfoundland Ridge by Pitman and Talwani (1972) and Rabinowitz et al. (1978, 1979) (Fig. 3). Along all NB tracks north of the Southeast Newfoundland Ridge, the residual magnetic field exhibits a dual character (Fig. 4). Over the outer slope and rise of the Grand Banks and the inner half of the Newfoundland/Flemish Basin, the anomaly field is relatively smooth. However, along a trend approximated by the 4000-m bathymetric contour, the residual field changes character abruptly. We interpret the landward shoulder of the observed high-amplitude, double-peaked anomaly as the $\mathbf{J}$ anomaly, which appears to be well developed north of the Newfoundland Seamounts (Figs. 3 and 4).

The $\mathrm{J}$ anomaly appears to be the oldest seafloor-spreading lineation that can be positively identified both seaward of the southeastern Grand Banks and west of the Iberian Peninsula (Klitgord and Schouten, 1986; Sibuet et al., 1987; Figs. 1 and 2). As added corroboration that the $J$ anomaly is in fact a iso- chron, Le Pichon et al. (1977) have used it in an effective reconstruction of the pre-drift configuration of this part of the North Atlantic (Fig. 2).

The $\mathrm{J}$ anomaly appears to be associated with basement topographic features on both sides of the North Atlantic, that is, the Madeira-Tore Rise, a basement ridge trending along the foot of the Iberian continental margin (Pitman and Talwani, 1972; Rabinowitz et al., 1979; Sibuet et al., 1987), and the J anomaly ridge south of the Grand Banks (Tucholke and Ludwig, 1982; Fig. 3). This observation is further supported by a comparison of the acoustic basement structure of the northern Newfoundland/Flemish Basin near the $\mathrm{J}$ anomaly with that found in the vicinity of ODP Site 637 (Figs. 5A and 5B). Le Pichon et al.'s (1977) reconstruction of the North Atlantic at the time of the J anomaly suggests that the approximate paleoposition of ODP Site 637 is about $800 \mathrm{~km}$ northeast of the intersection of MCS profile NB-4B and the $\mathrm{J}$ anomaly (Figs. 2 and 4). Acoustic basement at Site 637 has both high relief (approximately $2.0 \mathrm{~s}$ traveltime) and an internally chaotic structure (Fig. 5A). Strata overlying surrounding acoustic basement onlap this buried ridge. Where this ridge crops out at the seafloor, serpentinized peridotite has been dredged (Boillot et al., 1980). Drilling at Site 


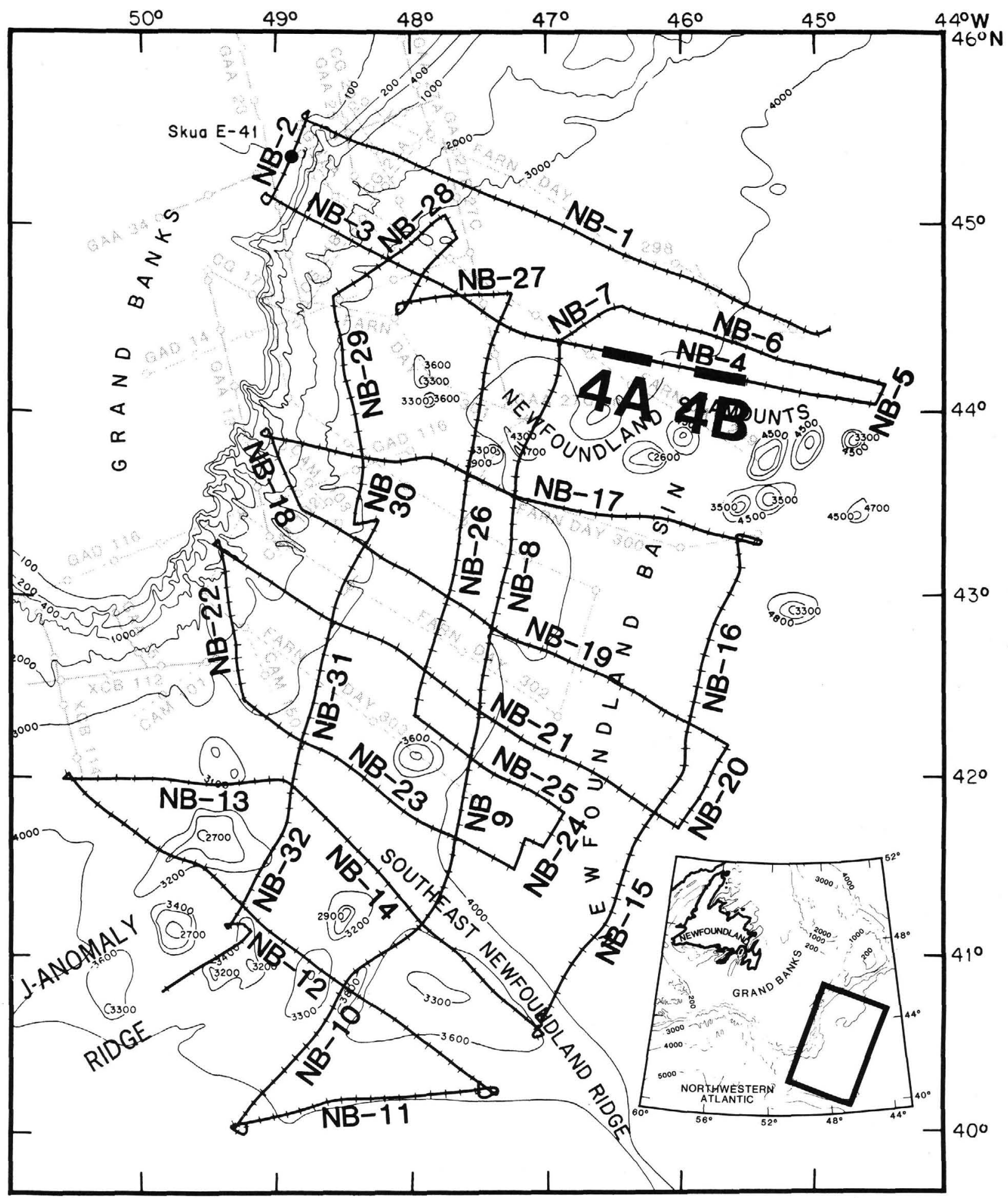

Figure 3. Bathymetry of the Newfoundland/Flemish Basin, with location of NB MCS grid, Skua E-41 well, and available industry MCS and Farnella single-channel profiles (from Parson et al., 1985). Profiles used in Figures 5B (NB-4B) and 6 (NB-4A) are highlighted. Inset (lower right) shows part of the eastern Canadian passive continental margin and location of the survey area (after Meador et al., in press).

637 has also recovered serpentinized peridotite from this feature, which has been interpreted as mantle believed to have been emplaced during late-stage rifting, probably as a result of lithospheric stretching (Boillot, Winterer, et al., 1987). However, although it is approximately collinear with the $\mathrm{J}$ anomaly trend in the Le Pichon et al. (1977) reconstruction (Fig. 2), the ridge at Site 637 exhibits no anomalous magnetic signature. Magnetic anomalies in this area have been difficult to identify, perhaps because of rotation of faulted blocks nearby (Verhoef et al., 1986; Sibuet et al., 1987). The serpentinization of peridotite 


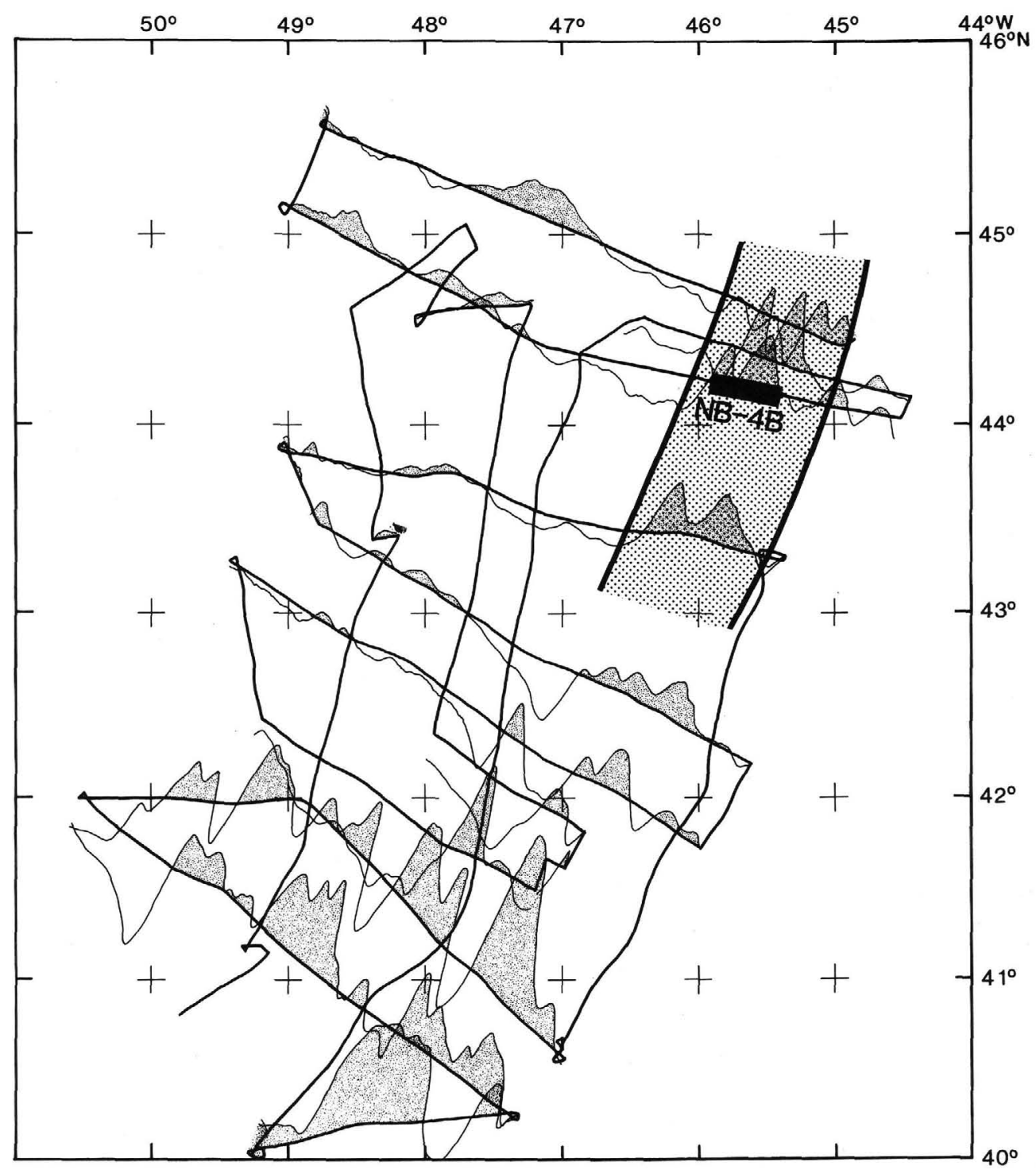

Figure 4. Magnetic anomalies plotted along dip lines of the NB survey. Shaded area is positive. Approximate trend of the $\mathbf{J}$ anomaly (M0-M1) in the northern Newfoundland/Flemish Basin is highlighted (after Meador et al., in press). Note location of MCS profile NB-4B (Fig. 5B).

might also explain the ridge's low magnetic intensity, although this has not yet been confirmed (Boillot, Winterer, et al., 1987).

The part of profile NB-4B (Fig. 5B) that crosses the J anomaly trend north of the Newfoundland Seamounts (Figs. 3 and 4) also coincides with a major change in the morphology of acoustic basement. Tilted, steep-sided (faulted?), and apparently layered basement blocks to the west (landward) give way to rougher, shallower, internally chaotic basement to the east (seaward). This change in crustal morphology, which mirrors the major change in the residual magnetic field (Fig. 4), has been interpreted to mark the ocean/continent boundary in the Newfoundland/Flemish Basin (Meador et al., 1985, in press). The recovery at Site 637 of suboceanic mantle rocks emplaced by some kind of rifting process supports an interpretation that the peridotite ridge southwest of Galicia Bank is a northeastward extension of the same ocean/continent boundary (Fig. 2), even though the $\mathrm{J}$ anomaly is not recognized at the Leg 103 site.

\section{Rift/Early Drift History}

Acoustic basement landward of the $\mathrm{J}$ anomaly in the Newfoundland/Flemish Basin forms flat-topped, fault-bounded(?), and rotated blocks (Figs. 3 and 6). Internal layering within most of these blocks appears to form angular unconformities with the overlying strata, although basement is occasionally difficult to distinguish from adjacent cover (Fig. 6). Meador et al. (in press) have interpreted acoustic basement in this part of the basin to be rifted continental(?) crust, extending almost $400 \mathrm{~km}$ seaward from the edge of the Grand Banks to the $\mathrm{J}$ anomaly trend.

Sequence 1 (S1) is the oldest seismic stratigraphic sequence identified in the deep Newfoundland/Flemish Basin (Meador, 1988). S1 can be identified west of the $J$ anomaly but is not present seaward (east) of it. S1 is highly variable in thickness, appears to fill asymmetric lows between basement blocks, and 
Table 1. Acquisition parameters for the NB MCS survey (Robert $D$. Conrad, LDGO).

Sound source:

4 Bolt air guns (Model 1500C) 466 in. $^{3}$

Channels recorded:

Stacking multiplicity:

Interval between input channels: $\quad 50 \mathrm{~m}$

Minimum offset distance: $\quad 300 \mathrm{~m}$

Maximum offset distance: $\quad 2650 \mathrm{~m}$

Static corrections:

Magnetics:

$90 \mathrm{~ms} / \mathrm{shot}$

VARIAN proton precession magnetometer with 200-m tow cable

Gravity:

GRAF-ASKANIA GSS gravity meter

is composed of moderately to strongly layered reflectors that onlap intervening basement (Fig. 6). The similar reflectivities of $\mathrm{S} 1$ and basement suggest that $\mathrm{S} 1$ is composed in part of material eroded from adjacent blocks, whereas intermittent high amplitudes (e.g., Fig. 6, $1600 \mathrm{hr}$ ) indicate the possible presence of volcanics, which are perhaps associated with rifting. However, the lack of large magnetic anomalies over this part of the Newfoundland/Flemish Basin argues against a significant volcanic component. Farther landward, diapirs appear to root in these basement basins, suggesting that these rifts(?) saw repeated cycles of marine incursion (Austin et al., in press).

The top of S1 is generally convergent with the tops of basement blocks and is distinguished from the overlying sequences by a high-amplitude, continuous reflector (Fig. 6). On NB-2 at the Skua E-41 well, Meador et al. (in press) have correlated this reflector to an unconformity of late Early Cretaceous age, which has been observed elsewhere on the Grand Banks and termed the "U" unconformity (Amoco and Imperial, 1973; Grant, 1977). Meador et al. (1985, in press) have traced the U unconformity from the Skua E-41 well site across the shelf and slope to the northern part of the deep Newfoundland Basin, where it pinches out at the morphologic transition in acoustic basement associated with the $\mathrm{J}$ anomaly (Fig. 5B). This stratigraphic relationship supports an interpretation that the $U$ unconformity is approximately coeval with the formation of the crust which generated that magnetic anomaly in the late Early Cretaceous.

Sequence 2 (S2) constitutes the oldest sediments immediately overlying the U unconformity in the deep Newfoundland/Flemish Basin (Fig. 6). S2 is composed of low- to medium-amplitude, discontinuous reflectors that onlap underlying basement topography. Meador et al. (in press) have correlated the top of S2 with the top of a Cenomanian limestone at the Skua E-41 well on the Grand Banks.

\section{COMPARISON OF RIFT/EARLY DRIFT SEISMIC STRATIGRAPHIC FRAMEWORKS: NEWFOUNDLAND/FLEMISH BASIN AND THE IBERIAN ABYSSAL PLAIN}

Based on a comparison of seismic facies imaged by NB-4 (Figs. 5 and 6) and MCS profile GP-19 in the Iberian Abyssal Plain at DSDP Site 398 (Group Galice, 1979; Figs. 2 and 7), we correlate the uppermost part of S1 with Formation 4 southwest of Galicia Bank (Fig. 8). As is the case in the Newfoundland/ Flemish Basin landward of the $\mathrm{J}$ anomaly, acoustic basement on MCS profile GP-19 appears as rotated, faulted blocks separated by asymmetrical troughs (Fig. 7). Formation 4 infills these basement troughs, as does S1, and component reflectors of both sequences commonly diverge downdip to form asymmetrical, fan-shaped patterns between blocks (Fig. 7). Using such seismic evidence and results from Site 398, Group Galice (1979) has interpreted Formation 4 as an Lower Cretaceous (pre-Albian) synrift sequence deposited during active faulting and tilting of basement blocks. Leg 103 drilling at Site 638 has confirmed that
Formation 4 is composed of syn-rift sediments: upper Valanginian-Hauterivian terrigenous turbidites overlain by Hauterivian pelagic marlstones and calcareous claystone turbidites (Boillot, Winterer, et al., 1987; Fig. 2).

The top of Formation 4 is defined by a high-amplitude, continuous reflector interpreted by Groupe Galice (1979) as the Aptian/Albian boundary between rift and drift sedimentation west of Iberia (Fig. 7). Based on both similar seismic character and age, we correlate the $U$ unconformity southeast of the Grand Banks to the Formation 3/Formation 4 sequence boundary in the Iberian Abyssal Plain at Site 398 (Fig. 8). This comparison provides an independent corroboration of the stratigraphic accuracy of our shelf-to-basin correlation of the U unconformity and also underscores its stratigraphic significance as the rift-drift transition along part of the eastern Canada passive continental margin. The Formation 3/Formation 4 boundary at Site 398 is associated with a small hiatus(?) separating upper Aptian and lower Albian strata, although it does not form an obvious angular unconformity in Site 398 cores (Group Galice, 1979). However, the Formation 3/Formation 4 boundary at Site 398 is associated with an abrupt change in lithology from dark, marly mudstone with abundant debris flows and turbidites (the interpreted syn-rift sequence) below to laminated black shale (the drift sequence) above (Groupe Galice, 1979). A similar and coeval lithologic change occurs at the Formation 3/Formation 4 boundary at Site 641 (Boillot, Winterer, et al., 1987). In both places, the lithologic contrast is coeval with or a little later than M0-M1, the J anomaly. More precisely, the M0 anomaly was identified by Ogg (this volume) about $40 \mathrm{~m}$ beneath the Formation 3/4 boundary, near the base of the Aptian, at Site 641. Despite the absence of the J anomaly southwest of Galicia Bank, the combined evidence suggests an end of rifting and initiation of drifting there and on the Newfoundland margin during the late Early Cretaceous.

For several reasons, we consider Formation 3 beneath the eastern Iberian Abyssal Plain to be acoustically and stratigraphically equivalent to $\mathrm{S} 2$ in the Newfoundland/Flemish Basin (Figs. 6 and 7). First, Formation 3 directly overlies the Albian-Aptian rift-drift transition sampled at DSDP Site 398, and is interpreted as the oldest drift sequence there (Group Galice, 1979). We also interpret S2 as the oldest drift sequence southeast of the Grand Banks because it immediately overlies the U unconformity (Figs. 6-8). Second, S2 and Formation 3 are both composed of low-amplitude, discontinuous reflectors that blanket underlying basement topography (Figs. 6-8). Traveltime thicknesses of both sequences are also generally comparable, approximately $0.5 \mathrm{~s}$, at their closest estimated point of approach based on the Le Pichon et al. (1977) pre-drift reconstruction (Fig. 8). Finally, the two seismic sequences appear to be approximately coeval. At Site 398, Formation 3 is composed of lower Albian to middle Cenomanian mudstone, shale, and organic-rich distal turbidites (Groupe Galice, 1979), whereas at Site 641, Formation 3 is composed of Albian-Cenomanian black shale (Boillot, Winterer, et al., 1987). Both sets of drilling results are consistent with the Cenomanian (or older) age proposed for S2 (Meador et al., in press).

\section{DISCUSSION AND CONCLUSIONS}

A comparison of the northern Newfoundland/Flemish Basin and part of the Iberian margin using MCS seismic profiles and stratigraphic results from DSDP Site 398 and ODP Leg 103 sites shows similar late rift and early drift seismic sequences and a correlative intervening sequence boundary interpreted as the break-up unconformity. Acoustic basement at Site 637 is similar in character to acoustic basement along the part of profile NB$4 \mathrm{~B}$ crossing the trend of the $J$ anomaly north of the Newfoundland Seamounts. Along with drilling results at Site 637, this information supports an interpretation that the $\mathrm{J}$ anomaly and/or 


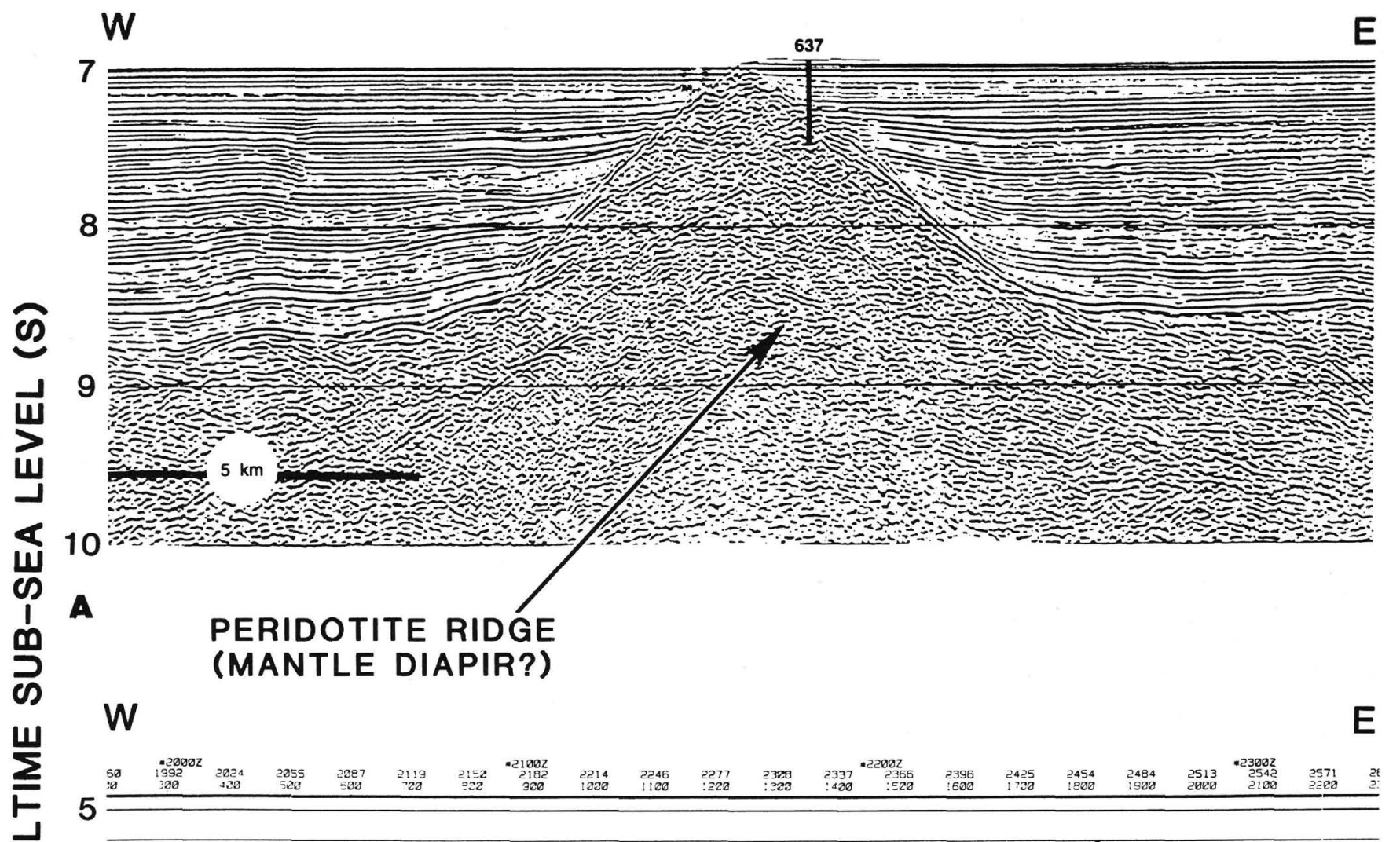

E
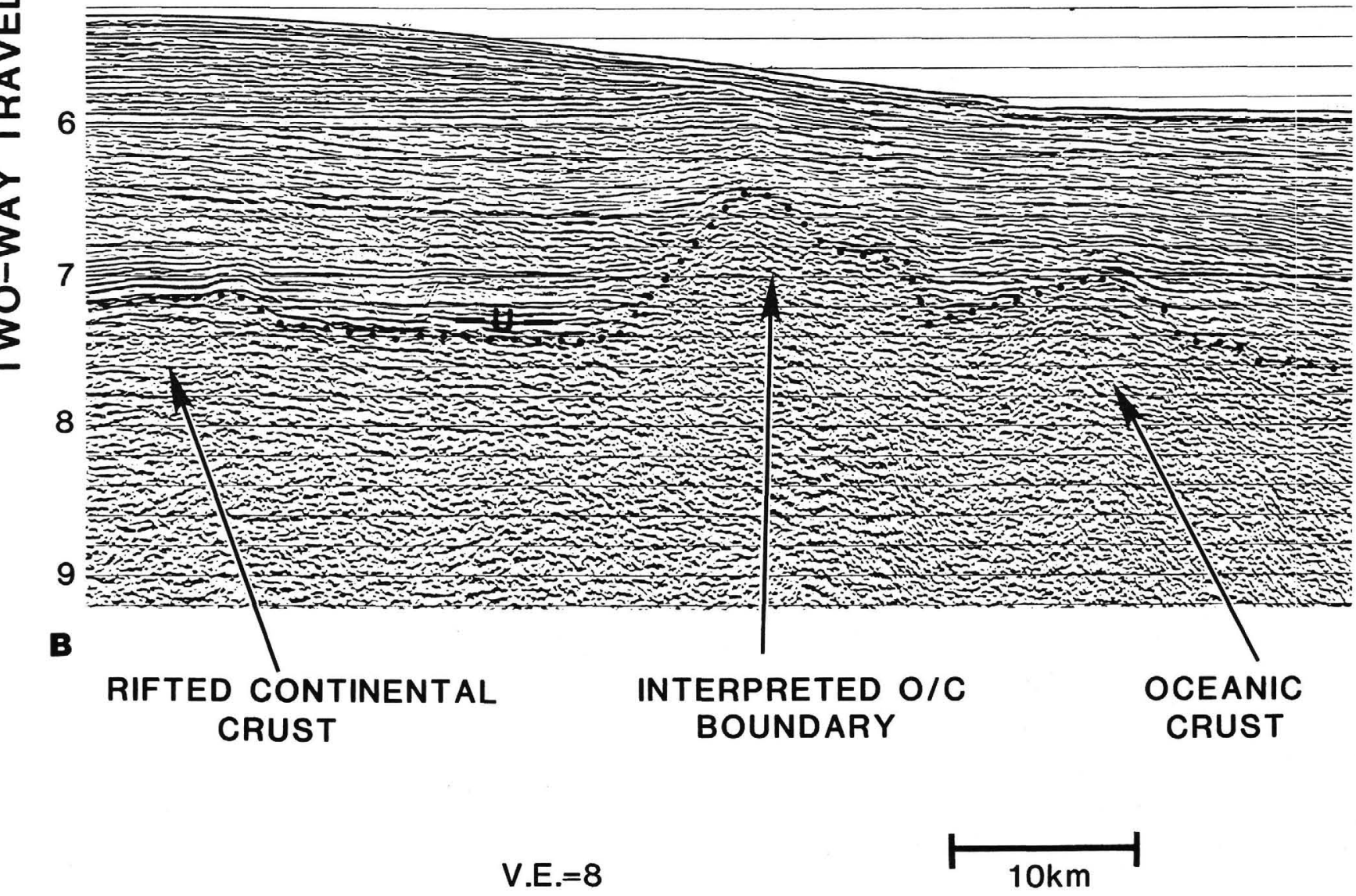

Figure 5. Comparison of inferred ocean/continent boundaries at the Galicia margin and in the northern Newfoundland/Flemish Basin. A. Seismicreflection profile GP-12, with location of ODP Leg 103 Site 637 (modified from Boillot, Winterer, et al., 1987). B. Portion of seismic-reflection profile NB-4B crossing the trend of the J anomaly (see Fig. 4). Note the pronounced change in acoustic basement morphology associated with the magnetic anomaly. 
W

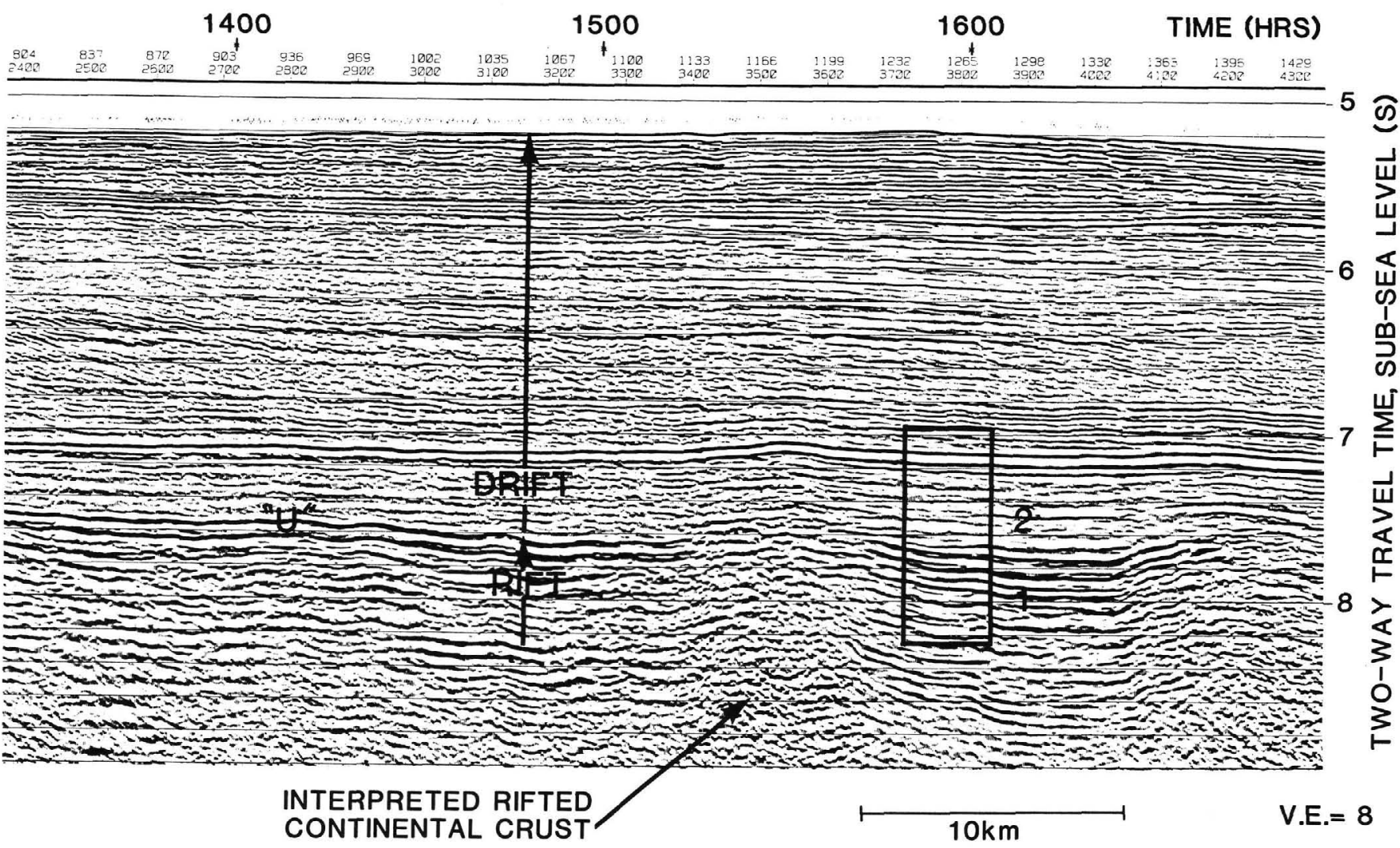

Figure 6. Portion of MCS profile NB-4A landward of the J anomaly (see also Fig. 3). Seismic sequences S1 ("rift"), S2 ("drift"), and the intervening $\mathrm{U}$ unconformity are shown. Box shows location of enlargement shown in Figure 8.

a pronounced change in crustal morphology mark the ocean/ continent boundary along these conjugate passive continental margins.

Acoustic Formation 4 and Formation 3 recognized on the Galicia margin are stratigraphically equivalent to sediments comprising seismic sequences $\mathrm{S} 1$ and S2 in the Newfoundland/Flemish Basin, respectively. The S1/Formation 4 pair correspond to a late syn-rift sequence, whereas S2/Formation 3 represent early drift sediments. Tankard and Welsink (1987) have recently documented two phases of rifting on the Grand Banks: the first associated with the separation of Africa and North America during the Late Triassic-Early Jurassic and the second related to the separation of Iberia and Grand Banks during the Late JurassicEarly Cretaceous. At present, we cannot differentiate these multiple rifting events systematically within S1 in the northern Newfoundland/Flemish Basin, so we can only correlate the uppermost part of S1 with Formation 4, a pre-Albian (but not Upper Jurassic) syn-rift sequence at Site 398 (Group Galice, 1979). Leg 103 results at Sites 638,639 , and 641 support this correlation. Lower Cretaceous syn-rift deposits recovered at these sites suggest that rifting west of Iberia extends back at least to the Valanginian (Boillot, Winterer, et al., 1987).

The U unconformity, previously identified on the Grand Banks (Amoco and Imperial, 1973; Grant, 1977) and recently carried seaward into the Newfoundland/Flemish Basin (Meador et al., 1985, in press), correlates in both age and seismic signature with the Formation 3/Formation 4 sequence boundary south of Galicia Bank (Group Galice, 1979). The U unconformity appears to form the upper Lower Cretaceous rift/drift transition in the Newfoundland/Flemish Basin, as does the Formation 3/
Formation 4 boundary west of Iberia (Boillot, Winterer, et al., 1987).

$\mathrm{S} 2$ in the Newfoundland/Flemish Basin and Formation 3 are both earliest drift sequences. These sequences are acoustically similar, and both blanket underlying basement structure. Where Formation 3 has been sampled southwest of Galicia Bank, it appears to consist of an Albian-Cenomanian black shale sequence. A similar lithologic interpretation for $\mathrm{S} 2$ seems reasonable at this time.

\section{ACKNOWLEDGMENTS}

We are indebted to the captain and crew of the Robert $D$. Conrad for their help in successfully carrying out the NB MCS survey. J. C. Crowe and D. F. Dean of UTIG provided seismic data processing support, and M. I. Ross of UTIG generated the magnetic anomaly profiles. N. Kelly of UTIG drafted the illustrations. We especially thank B. E. Tucholke of WHOI, co-principal investigator of the NB project and co-chief scientist during the Conrad survey, for his continuing input and encouragement. This manuscript was reviewed by J. Ladd and E. Uchupi.

Funding for this work was provided jointly by the Division of Ocean Sciences and the Ocean Drilling Program of the National Science Foundation through grant OCE-8308623. University of Texas Institute for Geophysics Contribution no. 732.

\section{REFERENCES}

Amoco Canada Petroleum Company, Ltd., and Imperial Oil, Ltd., 1973. Regional geology of the Grand Banks. Bull. Can. Pet. Geol., 21: 479-503.

Austin, J. A., Jr., Meador, K. J., and Tucholke, B. E., 1987. Seismic stratigraphy of the northern Newfoundland Basin. Eos, Trans. Am. Geophys. Union, 68:1480. (Abstract) 
Austin, J. A., Jr., Tucholke, B. E., and Uchupi, E., in press. Upper Triassic-Lower Jurassic salt basin southeast of the Grand Banks of Canada. Earth Planet. Sci. Lett.

Boillot, G., Grimaud, S., Mauffret, A., Mougenot, D., Mergiol-Daniel, J., Kornprobst, J., and Torrent, G., 1980. Ocean-continental boundary off the Iberian margin: a serpentinite diapir west of Galicia Bank. Earth Planet. Sci. Lett., 48:23-34.

Boillot, G., Winterer, E. L., et al., 1987. Proc. ODP, Init. Repts., 103: College Station, TX (Ocean Drilling Program).

Grant, A. C., 1977. Multichannel seismic reflection profiles of the continental crust beneath the Newfoundland Ridge. Nature, 270:22-25.

Group Galice, 1979. The continental margin off Galicia and Portugal: acoustical stratigraphy, dredge stratigraphy and structural evolution. In Sibuet, J.-C., Ryan, W.B.F., et al., Init. Repts. DSDP, 47, Pt. 2: Washington (U.S. Govt. Printing Office), 633-662.

Jansa, L. F., and Wade, J. A., 1975. Geology of the continental margin off Nova Scotia and Newfoundland. In Offshore geology of eastern Canada: Pap. Geol. Surv. Can., 74-30:51-105.

Keen, C. E., Hall, B. R., and Sullivan, K. D., 1977. Mesozoic evolution of the Newfoundland Basin. Earth Planet. Sci. Lett., 37:307-320.

Klitgord, K. D., and Schouten, H., 1986. Plate kinematics of the central Atlantic. In Vogt, P. R., and Tucholke, B. E. (Eds.), The Geology of North America: The Western Atlantic Region: Geol. Soc. Am., DNAG Ser., 1:351-378.

Le Pichon, X., Sibuet, J.-C., and Francheteau, J., 1977. The fit of the continents around the North Atlantic Ocean. Tectonophysics, 28: 169-209.

Masson, D. G., and Miles, P. R., 1984. Mesozoic seafloor spreading between Iberia, Europe and North America. Mar. Geol., 56:279-287.

Meador, K. J., 1988. Seismic stratigraphy of the northern Newfoundland Basin [thesis]. Univ. of Texas at Austin.

Meador, K. J., Austin, J. A., Jr., and Dean, D. F., in press. Shelf-to-basin correlations off eastern Canada: developing a seismic stratigraphic framework in the northern Newfoundland Basin. AAPG Stud. Geol.

Meador, K. J., Austin, J. A., Jr., and Tucholke, B. E., 1985. Shelf to basin correlations in the Newfoundland Basin. Eos, Trans. Am. Geophys. Union, 66:1105. (Abstract)

Parson, L. M., Masson, D. G., Pelton, C. D., and Grant, A. C., 1985. Seismic stratigraphy and structure of the east Canadian continental margin between $41^{\circ} \mathrm{N}$ and $52^{\circ} \mathrm{N}$. Can. J. Earth Sci., 22:686-703.
Pitman, W. C., III, and Talwani, M., 1972. Sea-floor spreading in the North Atlantic. Geol. Soc. Am. Bull., 83:619-646.

Rabinowitz, P. D., Cande, S., and Hayes, D. E., 1978. Grand Banks and J-Anomaly Ridge. Science, 202:71-73.

, 1979. The J-Anomaly in the central North Atlantic Ocean. In Tucholke, B. E., Vogt, P. R., et al., Init. Repts. DSDP, 43 Washington (U.S. Govt. Printing Office), 879-885.

Sibuet, J.-C., Mazé, J.-P., Amortila, P., and Le Pichon, X., 1987. Physiography and structure of the western Iberian continental margin off Galicia, from Sea Beam and seismic data. In Boillot, G., Winterer, E. L., et al., Proc. ODP, Init. Repts., 103: College Station, TX (Ocean Drilling Program), 77-97.

Sullivan, K. D., 1983. The Newfoundland Basin: ocean-continent boundary and Mesozoic seafloor spreading history. Earth Planet. Sci. Lett., 62:321-339.

Tankard, A. J., and Welsink, H. J., 1987. Extensional tectonics and stratigraphy of Hibernia oil field, Grand Banks, Newfoundland. AAPG Bull., 71:1210-1232.

Tucholke, B. E., and Ludwig, G. S., 1982. Structure and origin of the JAnomaly Ridge, western North Atlantic. J. Geophys. Res., 87:93899407.

Tucholke, B. E., and Mountain, G. S., 1979. Seismic stratigraphy, lithostratigraphy and paleosedimentation patterns in the North American basin. In Talwani, M., Hay, W., and Ryan, W.B.F. (Eds.), Deep Drilling Results in the Atlantic Ocean: Continental Margins and Paleoenvironment: Am. Geophys. Union, Maurice Ewing Ser., 3:5886.

, 1986. Tertiary paleoceanography of the western North Atlantic Ocean. In Vogt, P. R., and Tucholke, B. E. (Eds.), The Geology of North America, The Western North Atlantic Region: Geol. Soc. Am., DNAG Ser., 1:631-650.

Verhoef, J., Collette, B. J., Miles, P. R., Searle, R. C., Sibuet J.-C., and Williams, C. A., 1986. Magnetic anomalies in the northeast Atlantic Ocean $\left(35^{\circ}-50^{\circ}\right.$ N). Mar. Geophys. Res., 8:1-25.

Date of initial receipt: 2 July 1987

Date of acceptance: 5 January 1988

Ms 103B-184

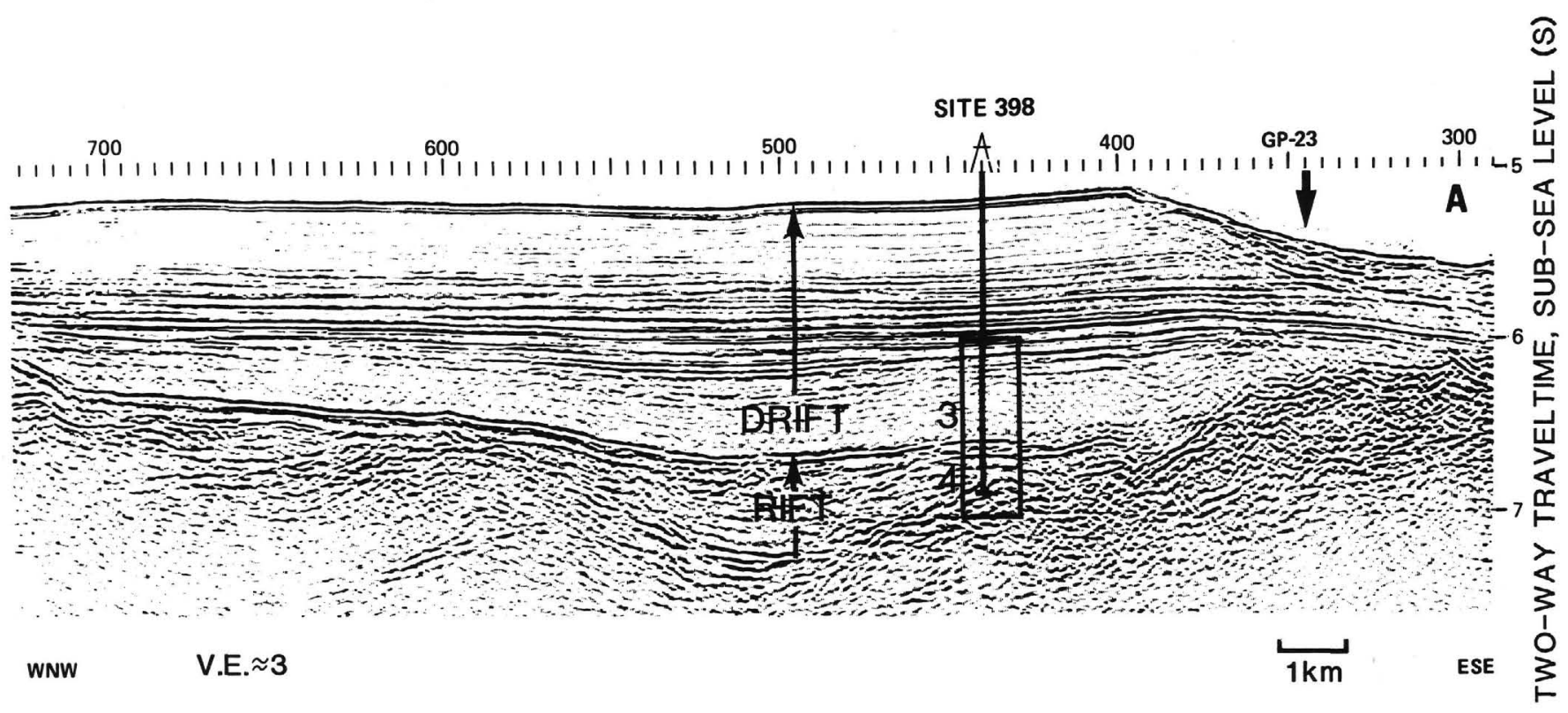

Figure 7. True-amplitude, stacked, migrated time section of MCS profile GP-19 from the Iberian conjugate margin (Group Galice, 1979; see Fig. 2 for location). The location of DSDP Site 398 is also shown, with interpretation of syn-rift/early drift sequences taken from Groupe Galice (1979). Note similarity of these sequences and the Formation 3/Formation 4 sequence boundary to the rift/early drift sequences and the U unconformity on NB4A in the Newfoundland/Flemish Basin (Fig. 6). Box shows portion of this profile reproduced and enlarged as part of Figure 8. 


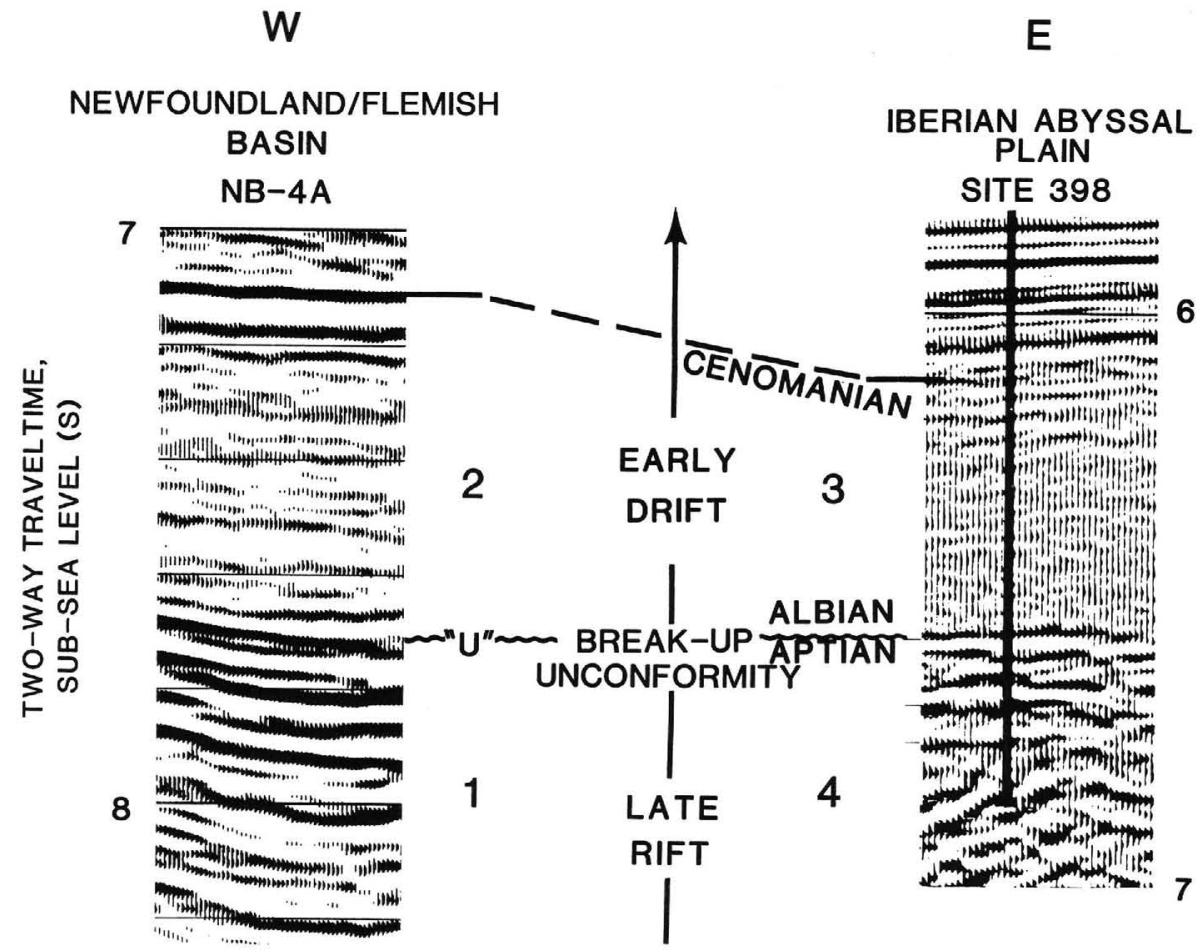

Figure 8. Comparison of late rift/early drift seismic stratigraphy developed for the northern Newfoundland/Flemish Basin and the Iberian margin in the vicinity of DSDP Site 398. Both sections show a high-amplitude, complexly layered, interpreted late syn-rift sequence, an intervening prominent, high-amplitude break-up or rift/drift unconformity, and a lower amplitude, interpreted early drift sequence. 